\title{
Sol-Gel Synthesis of NiO Nanoparticles and Investigation on Adsorption Capacity in the Removal of $\mathrm{Cr}(\mathrm{VI})$ from Aqueous Solution
}

\author{
SABER KHODAEI ASHAN ${ }^{1}$, NASIM ZIAEIFARA ${ }^{1}$ and MORTEZA KHOSRAVI ${ }^{2,1}$
}

'Department of Science, Maragheh Branch, Islamic Azad University, Maragheh, Iran. 2Department of Applied Chemistry, North Tehran Branch, Islamic Azad University Iran.

${ }^{*}$ Corresponding author e-mail : khosravi.morteza93@gmail.com

http://dx.doi.org/10.13005/ojc/320184

(Received: September 03, 2015; Accepted: January 23, 2016)

\section{ABSTRACT}

In this study, the $\mathrm{NiO}$ nanoparticles were synthesized by sol-gel method, and their physicochemical properties were investigated through XRD, SEM-EDX, TEM, and BET-BJH. The TEM results showed that average nanoparticles size was smaller than $10 \mathrm{~nm}$ and that there was a good agreement between the TEM and XRD results. The results indicate that $\mathrm{NiO}$ nanoparticles are efficient adsorbent for the removal of $\mathrm{Cr}(\mathrm{VI})$ from aqueous solutions. The effects of adsorbent, adsorbate concentration, and $\mathrm{pH}$ were examined. The equilibrium data could be well described by Sips model. The results of adsorption kinetics study indicated that kinetics obeyed pseudo-second order kinetic model.
\end{abstract}

Key words: NiO Nanoparticles, Sol-gel Method, Adsorption, $\mathrm{Cr}(\mathrm{VI})$

\section{INTRODUCTION}

Chromium (VI) contamination in the ground and surface waters is a global problem that grows day by day. This pollutant is dangerous to the environment and human health ${ }^{1} . \mathrm{Cr}(\mathrm{VI})$ is used in industries such as metal plating, paint manufacturing, steel fabrication, leather tanning, etc ${ }^{2}$. Various methods including precipitation, ion exchange, reverse osmosis and adsorption have been used for the removal of $\mathrm{Cr}(\mathrm{VI})$ from aqueous solution ${ }^{3}$. Adsorption is an efficient and easy method which is widely used for wastewater treatment process and removal of heavy metal from aqueous solutions ${ }^{4}$. The $\mathrm{NiO}$, due to its high surface area and natural porosity that can interact with heavy metal ions, is a good candidate for the adsorption process ${ }^{5,6}$. Many types of natural and synthetic adsorbents have been used for adsorption of heavy metal ions from aqueous solution such as... Naeem et al. ${ }^{3}$ investigated kinetic and thermodynamic behavior of $\mathrm{Cd}(\mathrm{II}), \mathrm{Co}$ (II) and $\mathrm{Zn}$ (II) adsorption from aqueous solution by NiO. Song et al. ${ }^{7}$ found out that $\mathrm{NiO}$ nanosheets were efficient and recyclable adsorbent 
for dye pollutant removal, exhibiting much more favorable adsorptive properties than conventionally prepared nickel oxide powder obtained from thermal decomposition of nickel nitrate. Behnajady et al. ${ }^{8}$ investigated the adsorption capacity of $\mathrm{TiO}_{2}-\mathrm{P} 25$ nanoparticles in the removal of a monoazo dye from an aqueous solution. They showed that $\mathrm{TiO}_{2}-\mathrm{P} 25$ nanoparticles had comparable adsorption capacity to other metal oxide nanoparticles in the adsorption of organic dyes. Kumar et al. ${ }^{9}$ investigated the lowcost synthesis of metal oxide nanoparticles and their application in the adsorption of $\mathrm{Cr}(\mathrm{VI})$ in the aqueous solution. The prepared metal oxide nanoparticles $\left(\mathrm{ZnO}\right.$ and $\mathrm{SnO}_{2}$ ), with specific surface area of 15.75 and $24.48 \mathrm{~m}^{2} \mathrm{~g}^{-1}$, indicated 9.38 and $3.09 \mathrm{mg} \mathrm{g}^{-1}$ $\mathrm{Cr}(\mathrm{VI})$ adsorption capacity, respectively.

This paper, NiO nanoparticles were synthesized by sol-gel method and used as adsorbent for the removal of $\mathrm{Cr}(\mathrm{VI})$ from aqueous solution. The effects of solution temperature, $\mathrm{pH}$, initial $\mathrm{Cr}(\mathrm{VI})$ concentration, adsorbent dosage on adsorption capacity were investigated. The equilibrium data were tested with isotherm models, and the kinetics was deduced from the experimental results.

\section{MATERIALS AND METHODS}

All the materials used in this study were of analytical grade and were obtained from the Merck. The nickel nitrate hexa-hydrate $\left(\mathrm{Ni}\left(\mathrm{NO}_{3}\right)_{2} \cdot 6 \mathrm{H}_{2} \mathrm{O}\right)$ and citric acid were used for synthesis of $\mathrm{NiO}$ nanoparticles. The stock solutions of $\mathrm{Cr}(\mathrm{VI})$ were diluted with double distilled water to obtain working solutions of varying concentrations for further experiments. The $\mathrm{pH}$ was adjusted using $0.1 \mathrm{M} \mathrm{HCl}$ and $0.1 \mathrm{M} \mathrm{NaOH}$.

\section{Synthesis of NiO nanoparticles by sol - gel method}

In this study, nickel oxide nanoparticles were synthesized by sol-gel method, in which the nickel nitrate solution was dripped in citric acid solution for $2 \mathrm{~h}$. Then, the mixed solution was heated to $70{ }^{\circ} \mathrm{C}$ under mechanical stirring for about $18 \mathrm{~h}$. The gel was dried at $110^{\circ} \mathrm{C}$ for $24 \mathrm{~h}$ and finally calcined at 400 ${ }^{\circ} \mathrm{C}$ for $3 \mathrm{~h}$.

\section{Characterization methods}

The samples were characterized by using the following methods: X-ray diffraction (XRD) transmission electron microscopy (TEM), scanning electron microscopy (SEM) and energy dispersive X-ray (EDX).

\section{Adsorption experiments}

The adsorption experiments were carried out by adding a fixed amount of adsorbent to $100 \mathrm{~mL}$ of $\mathrm{Cr}(\mathrm{VI})$ solution at a given initial concentration and $\mathrm{pH}$ and at a fixed temperature. The reaction vessels were placed on stirring with a constant speed of 1000 rpm. After mixing them, $5 \mathrm{~mL}$ of solution was sampled

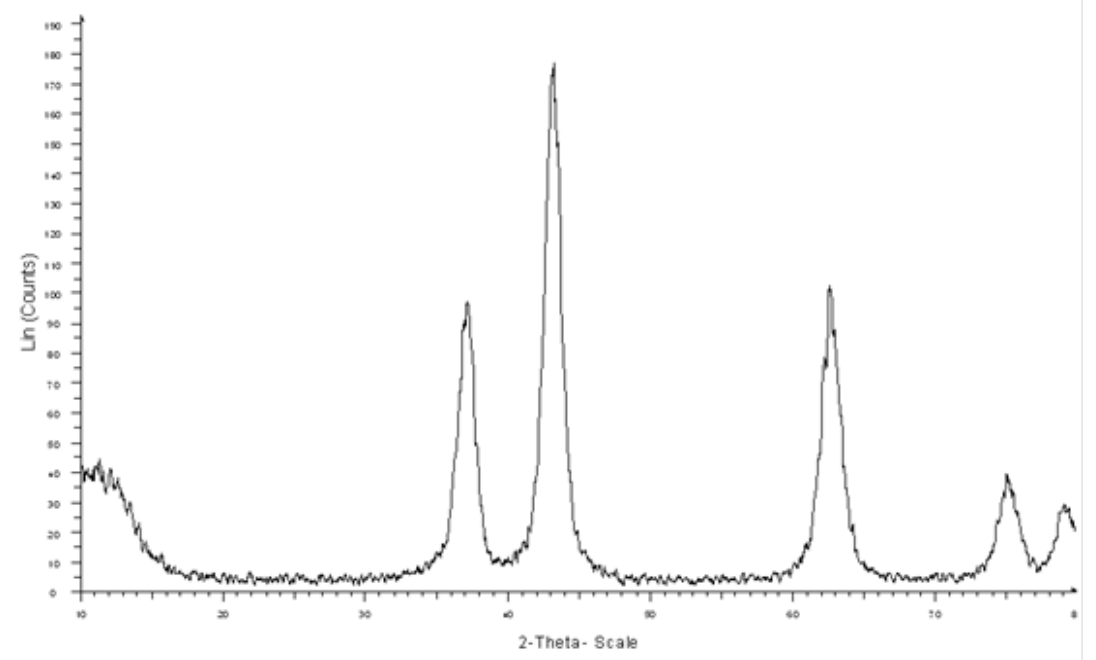

Scheme 1: The X-ray diffraction of NiO nanoparticles prepared by sol-gel method 
every $5 \mathrm{~min}$, and the solution was centrifuged for 5 min to separate the adsorbent. The Filtrate was analyzed through UV/Vis spectrophotometer in the maximum wavelength of $\mathrm{Cr}(\mathrm{VI}){ }^{10}$. The effect of the important parameters such as the initial concentration of $\mathrm{Cr}(\mathrm{VI}),(10,20,30,40,50,60 \mathrm{mg}$ $\left.\mathrm{L}^{-1}\right)$, dosage of the adsorbent $(0.1,0.2,0.3,0.4,0.5$, $0.6 \mathrm{~g})$ and initial $\mathrm{pH}(4.7,7,9)$ were also investigated. Then, the adsorption percentage was calculated by using Eq. 1 as follows:

Adsorption $\%=\frac{\left(C_{0}-C_{i}\right)}{C_{0}} \times 100$

where $\mathrm{C}_{0}$ and $\mathrm{C}_{i}$ are the initial and the final concentration of $\mathrm{Cr}(\mathrm{VI})$, respectively. The amount of $\mathrm{Cr}(\mathrm{VI})$ adsorbed per unit mass of adsorbent $\left(\mathrm{q}_{\mathrm{e}}\right)$ was calculated using Eq. 2 as follows:

$q_{e}=\frac{\left(C_{0}-C_{e}\right) \times V}{W}$

where $\mathrm{C}_{0}$ and $\mathrm{C}_{\mathrm{e}}$ represent the initial and equilibrium concentrations ( $\left.\mathrm{mg} \mathrm{L}^{-1}\right)$, respectively; $\mathrm{V}$ is the volume of the $\mathrm{Cr}(\mathrm{VI})$ solution $(\mathrm{L})$, and $\mathrm{W}$ is the weight of the $\mathrm{NiO}$ nanoparticles as adsorbent $(\mathrm{g})$.

\section{RESULT AND DISCUSSION}

\section{Characterization of $\mathrm{NiO}$ nanoparticles}

Fig. S1 illustrates the typical XRD pattern of $\mathrm{NiO}$ nanoparticles prepared by sol-gel method. The XRD pattern of $\mathrm{NiO}$ nanoparticles shows five primary peaks at $2 \bullet=37,43,63,75$ and $79^{\circ}$. As seen in the

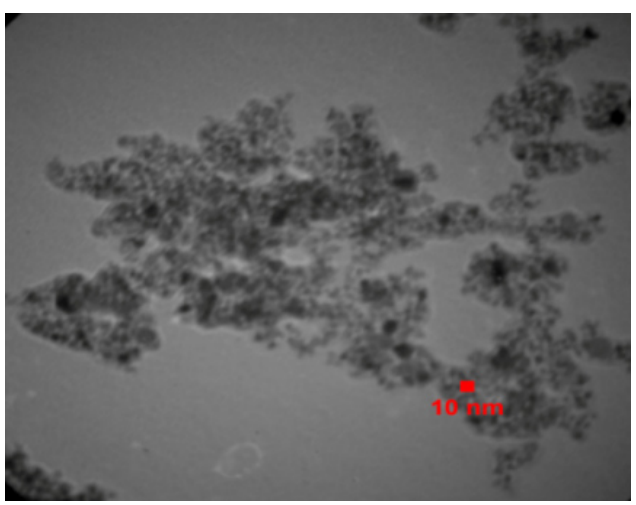

Scheme 2: TEM micrograph of NiO nanoparticles prepared by sol-gel method.
Figure, the diffraction peaks are broader and have weak intensity due to the small size of particles ${ }^{6}$. The crystallite size of $\mathrm{NiO}$ nanoparticles was estimated by Debye-Scherrer equation by using Eq. 3:

$$
D=\frac{K \lambda}{\beta \cos 2 \theta}
$$

The average crystallite size of $\mathrm{NiO}$ nanoparticles was about $7 \mathrm{~nm}$. The $\mathrm{NiO}$ nanoparticles obtained from the precipitation method used in our previous work ${ }^{11}$ were larger in size $(11 \mathrm{~nm})$ than those prepared by the sol-gel method used in the present study. This indicates that the sol-gel method can be used for the synthesis of smaller nanoparticles.

Typical TEM image of $\mathrm{NiO}$ nanoparticles is shown in scheme 2. There is a good agreement between the TEM and XRD results for the particle size. The average size of $\mathrm{NiO}$ nanoparticles, as measured by TEM, was found lower than $10 \mathrm{~nm}$.

The BET and BJH plots of nitrogen adsorption onto $\mathrm{NiO}$ nanoparticles are shown in scheme 3. The specific surface area and total pore volume of $\mathrm{NiO}$ nanoparticles were $109.36 \mathrm{~m}^{2} \mathrm{~g}^{-1}$ and $0.1993 \mathrm{~cm}^{3} \mathrm{~g}^{-1}$, respectively. The plot of the pore size distribution (scheme 4) was determined by using BJH method from the desorption branch of the isotherm. The pore size distribution of $\mathrm{NiO}$ nanoparticles measured $3.09 \mathrm{~nm}$. The $\mathrm{NiO}$ nanoparticles obtained from the precipitation method used in our previous

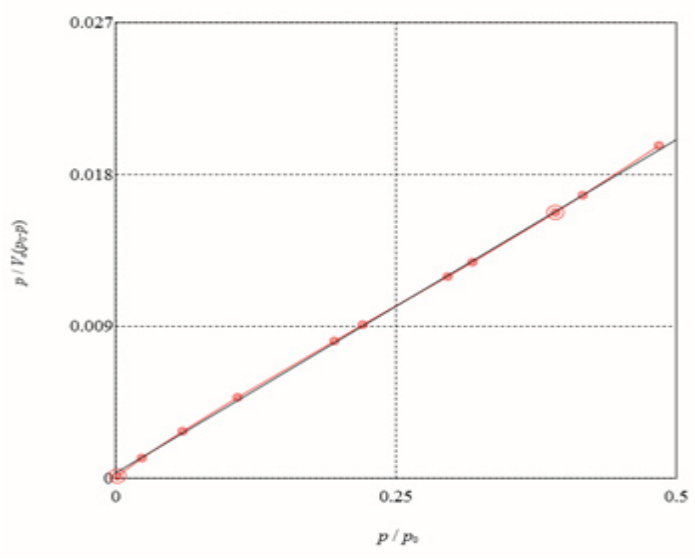

Scheme 3: BET plot of NiO nanoparticles prepared by sol-gel method. 
work ${ }^{11}$ had a low specific surface area and total pore volume compared to the $\mathrm{NiO}$ nanoparticles prepared by the sol-gel method $\left(71.09 \mathrm{~m}^{2} \mathrm{~g}^{-1}\right.$ and $\left.0.1761 \mathrm{~cm}^{3} \mathrm{~g}^{-1}\right)$ 11 .

The SEM micrograph in scheme 5 reveals the $\mathrm{NiO}$ nanoparticles have uniform size distribution.

The data in scheme 6 show the EDX spectra for $\mathrm{NiO}$ nanoparticles prepared by the sol-gel method, which clearly show the peaks of $\mathrm{Ni}$ and $\mathrm{O}$.

\section{Adsorption studies \\ The effect of $\mathrm{Cr}(\mathrm{VI})$ initial concentration}

The effect of $\mathrm{Cr}(\mathrm{VI})$ initial concentration on the adsorption percentage are shown in scheme 7 . According to the Figure, the percentage of adsorption decreases with an increase in the initial concentration of $\mathrm{Cr}(\mathrm{VI})$ so that for initial concentration of $\mathrm{Cr}(\mathrm{VI})$ of $10 \mathrm{mg} \mathrm{L}^{-1}, 0.2 \mathrm{~g}$ of adsorbent (NiO) dosage and $\mathrm{pH}=4.7$, about $67 \%$ of the $\mathrm{Cr}(\mathrm{VI})$ was adsorbed during a contact time of $30 \mathrm{~min}$, whereas for the initial concentration of $\mathrm{Cr}(\mathrm{VI})$ of $60 \mathrm{mg} \mathrm{L}^{-1}$, about $24 \%$ of the $\mathrm{Cr}(\mathrm{VI})$ was adsorbed during a contact time of $30 \mathrm{~min}$. This can be explained by the saturation adsorbent sites which cause the adsorbent to uptake more $\mathrm{Cr}(\mathrm{VI})$ molecules ${ }^{12,8}$. Other researchers have

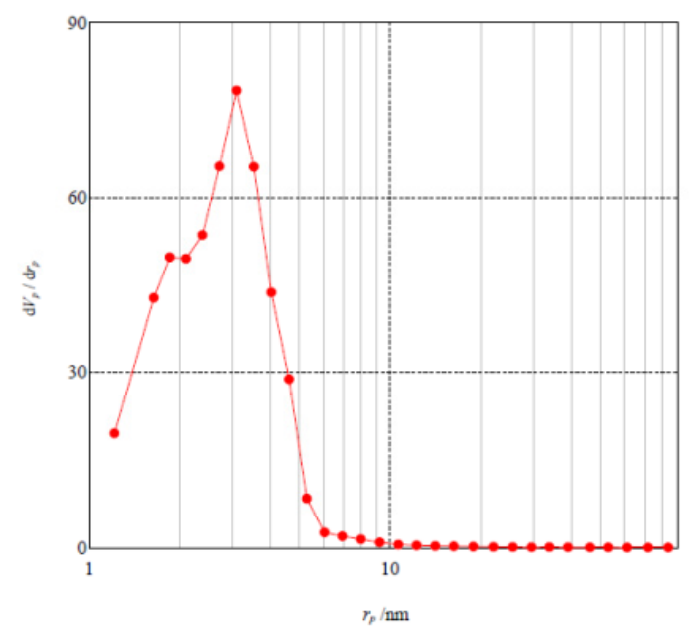

Scheme 4: BJH plot of NiO nanoparticles prepared by sol-gel method reported similar results for the adsorption of $\mathrm{Zn}$ on $\mathrm{NiO}$ nanoparticles and thallium (III) ion on $\mathrm{ZnO}$ nanoparticles ${ }^{13,14}$

\section{The effect of adsorbent (NiO) dosage}

The dosage of the $\mathrm{NiO}$ in the adsorption of $\mathrm{Cr}(\mathrm{VI})$ ranged from 0.1 to $0.6 \mathrm{~g}$. scheme 8 shows the effect of $\mathrm{NiO}$ nanoparticles dosage on the adsorption percentage of $\mathrm{Cr}(\mathrm{VI})$. According to the Figure, the removal percentage increased from $45 \%$ with 0.1 $\mathrm{g}$ of $\mathrm{NiO}$ nanoparticles to about $86 \%$ with a dosage of $0.6 \mathrm{~g}$. The increase of the adsorbent's dosage causes the increase of the adsorption sites, which, in turn, makes the surface area expand ${ }^{15,16}$. A number of researchers have reported similar results for the adsorption of $\mathrm{Cr}$ on $\mathrm{ZnO}$ and $\mathrm{SnO}_{2}$ and $\mathrm{Pb}$ (II) onto $\mathrm{NiO}$ nanoparticles ${ }^{9,17}$.

\section{The effect of initial pH}

The $\mathrm{pH}$ of solution is an important parameter in the adsorption of $\mathrm{Cr}(\mathrm{VI})$ onto $\mathrm{NiO}$ nanoparticles. The data in the scheme 9 indicate that the adsorption capacity increases significantly with a decrease in the $\mathrm{pH}$. As the $\mathrm{pH}$ of the system decreases, the surface of $\mathrm{NiO}$ becomes positively charged and is then neutralized by the dichromate $\left(\mathrm{Cr}_{2} \mathrm{O}_{7}^{2-}\right)$ ions present in the solution ${ }^{18}$. Research has shown similar results for the adsorption of $\mathrm{Cr}(\mathrm{VI})$ on $\mathrm{NiO}$ nanoparticles prepared by the precipitation method

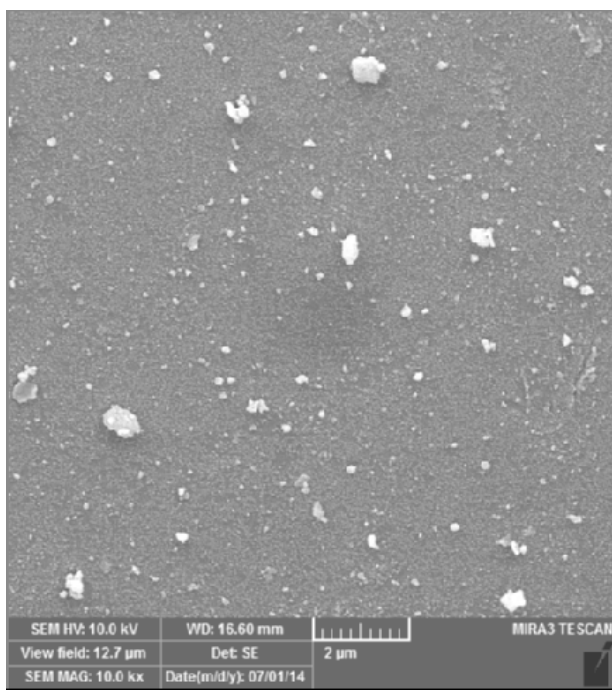

Scheme 5:The SEM image of $\mathrm{NiO}$ nanoparticles prepared by the sol-gel method. Scheme 5-The SEM image of $\mathrm{NiO}$ nanoparticles prepared by the sol-gel method. 
and adsorption of arsenate from aqueous solution on binary mixed oxide of iron on silicon ${ }^{11,4}$.

\section{Equilibrium isotherm studies}

Equilibrium characteristics, referred to as adsorption isotherms, describe how the adsorbate interacts with adsorbent ${ }^{19,20}$. The results indicated that the time needed to reach equilibrium, using 0.2 $\mathrm{g}$ of $\mathrm{NiO}$ nanoparticles with the $\mathrm{Cr}(\mathrm{VI})$ concentration in the range of $10-60 \mathrm{mg} \mathrm{L}^{-1}$, was $25 \mathrm{~min}$. In order to obtain the maximum adsorption capacity and other characteristics of $\mathrm{NiO}$ nanoparticles, the Langmuir, Freundlich, Temkin, Redlich-Peterson, Sips, Toth isotherms were used. The isotherm parameters were evaluated by non-liner trial and error method using Polymath 6.0 software. The results are demonstrated

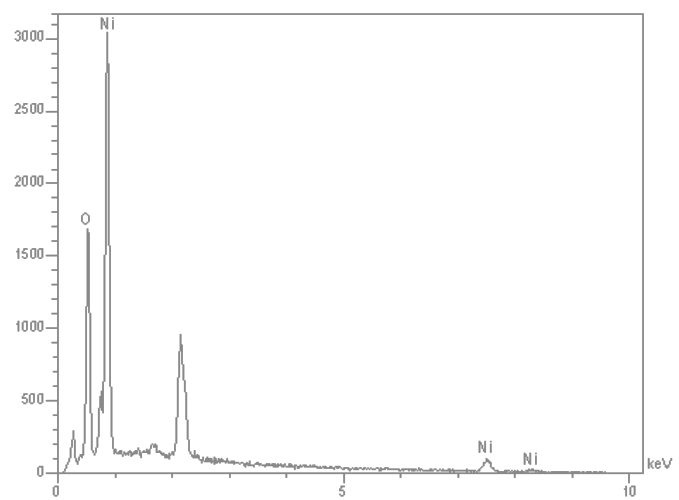

Scheme 6: EDX spectra of NiO nanoparticles prepared by sol-gel method.

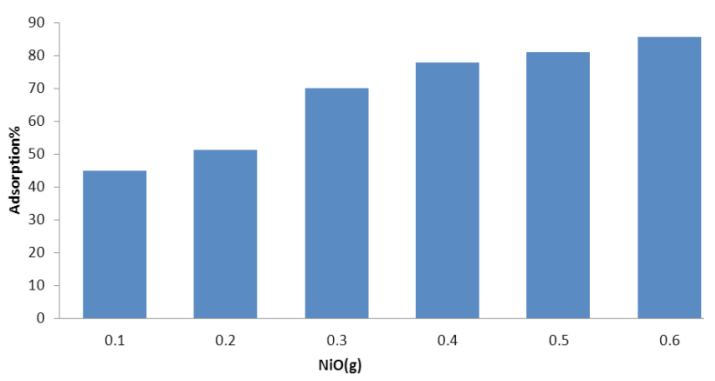

Scheme 8:The effect of $\mathrm{NiO}$ dosage on the adsorption capacity of $\mathrm{NiO}$ in the adsorption of $\mathrm{Cr}(\mathrm{VI})$ from aqueous solutions ([Cr]0 = $20 \mathrm{mg} \mathrm{L-1,} \mathrm{pH}=4.7, \mathrm{~T}=20 \mathrm{OC})$ in Table $1{ }^{21}$. Regression coefficient $\left(R^{2}\right)$, adjusted regression coefficient $\left(R^{2}{ }_{\text {adj }}\right)$, and root mean square error $\left(R_{m s d}\right)$ parameters were used to gauge the appropriateness of fit. Scheme 10 and scheme 11 show 2-parameter and 3-parameter isotherm models for the adsorption of $\mathrm{Cr}(\mathrm{VI})$ onto $\mathrm{NiO}$ nanoparticles, respectively.

\section{Langmuir isotherm}

The Langmuir equation is probably the best known adsorption isotherm ${ }^{22}$. This model is based on the following equation:

$q_{e}=\frac{q_{m} K_{L} C_{e}}{1+K_{L} C_{e}}$

where $\mathrm{C}_{\mathrm{e}}$ is the equilibrium concentration of solute (mg L $\left.\mathrm{L}^{-1}\right), \mathrm{q}_{\mathrm{e}}$ is the amount of adsorbate adsorbed at

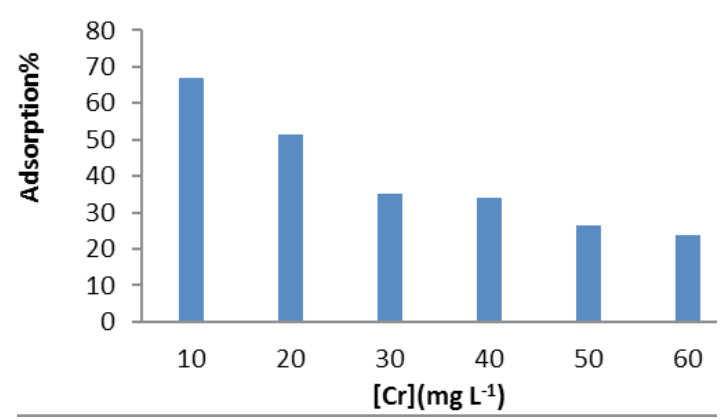

Scheme 7: The effect of initial $\mathrm{Cr}(\mathrm{VI})$ concentration on the adsorption of $\mathrm{Cr}(\mathrm{VI})$ from aqueous solutions $(\mathrm{NiO}=0.2 \mathrm{~g}, \mathrm{pH}=4.7, \mathrm{~T}=20 \mathrm{OC}$ )

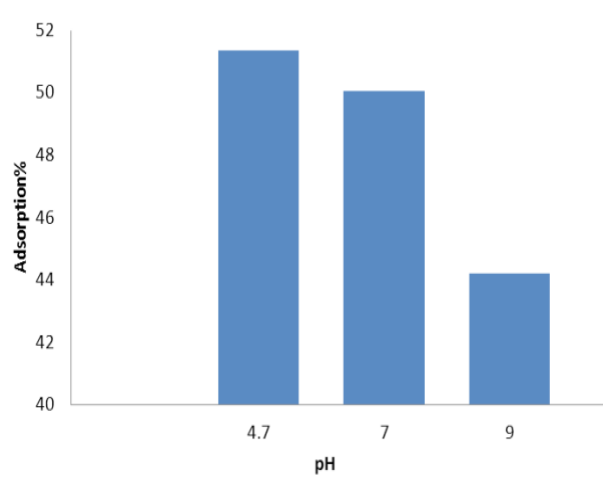

Scheme 9: The effect of initial pH on the adsorption capacity of $\mathrm{NiO}$ in the adsorption of $\mathrm{Cr}(\mathrm{VI})$ from aqueous solutions $([\mathrm{Cr}] 0=20$ $\mathrm{mg} \mathrm{L}-1, \mathrm{NiO}=0.2 \mathrm{~g}, \mathrm{~T}=20 \mathrm{OC}$ ) 
equilibrium $\left(\mathrm{mg} \mathrm{g}^{-1}\right), \mathrm{q}_{\mathrm{m}}$ is the maximum adsorption capacity, and $\mathrm{K}_{\mathrm{L}}$ is the Langmuir adsorption model constant $\left(\mathrm{L} \mathrm{mg}{ }^{-1}\right)$. The correlation coefficient $\left(R^{2}\right)$ was found to be 0.99007 for Langmuir, indicating a satisfactory fit to the experimental data and showing that the all the sites are uniform and the adsorbent has a homogeneous structure ${ }^{23}$.

The maximum mono-layer capacity $\left(q_{m}\right)$ obtained from Langmuir model was 7.63 $\mathrm{mg} \mathrm{g}^{-1}$. Table 2 lists maximum capacity of the mono-layer adsorption of $\mathrm{Cr}(\mathrm{VI})$ onto metal oxide nanoparticles reported in the literature. According to the results shown in the table, $\mathrm{NiO}$ nanoparticles prepared by sol-gel method in this work exhibited comparable adsorption capacity to other metal oxide nanoparticles but higher adsorption capacity than $\mathrm{NiO}$ nanoparticles prepared by precipitation method.

\section{Freundlich isotherm}

The Freundlich isotherm is an empirical equation employed to describe heterogeneous adsorption ${ }^{8}$. This model is based on the following equation:

$q_{\theta}=K_{F} C_{\theta}^{\frac{1}{n}}$

where $\mathrm{K}_{\mathrm{F}}$ is Freundlich adsorption model constant $\left(\mathrm{L} \mathrm{g}^{-1}\right)$ and $\mathrm{n}$ is a measure of the deviation from linearity of the adsorption. According to the results shown in Table 1, the $n$ value is 3.81 . Thus, the adsorption process is a chemical system. The $\mathrm{R}^{2}$ of the Freundlich isotherm is 0.98172 , showing that the experimental data are not in better agreement with this isotherm than with Langmuir isotherm.

\section{Temkin isotherm}

Temkin is concerned with determining the heat of adsorption and the adsorbate-adsorbate interactions ${ }^{24}$, and is represented by following equation

$$
q_{e}=\frac{R T}{\Delta Q} \operatorname{Ln}\left(K_{T} C_{\theta}\right)
$$

where $T$ is absolute temperature $(K), R$ is gas constant $\left(\mathrm{J} \mathrm{gmol}^{-1} \mathrm{~K}^{-1}\right), \mathrm{K}_{\mathrm{T}}$ is Temkin model constant $\left(\mathrm{L} \mathrm{mg}^{-1}\right)$ and $\mathrm{A} Q$ is the heat of adsorption $(\mathrm{J})$. ÄQ for adsorption of $\mathrm{Cr}(\mathrm{VI})$ onto $\mathrm{NiO}$ nanoparticles was $1705.16 \mathrm{~J} \mathrm{~mol}^{-1}$, which indicates an endothermic adsorption process.

\section{Redlich-Peterson isotherm}

This isotherm has the features of the both Langmuir and Freundlich isotherm equations ${ }^{8}$. This model is based on the following equation:

$$
q_{e}=\frac{A C_{e}}{1+B C_{e}^{g}}
$$

where $A$ and $B$ are Redlich-Peterson model constants $\left(\mathrm{L} \mathrm{mg}^{-1}\right)$ and $\mathrm{g}$ is model exponent. $\mathrm{R}^{2}$ value clearly shows that this isotherm can describe the experimental data fairly well. In this study, the $\mathrm{g}$ value is 0.94 , which indicates that the isotherm is approaching the Langmuir isotherm, since when $\mathrm{g}=1$, isotherm transforms to Langmuir model, and when $\mathrm{g}=0$, isotherm transforms to linear form of Freundlich isotherm (Henry's law).

\section{Sips isotherm}

The sips or Langmuir-Freundlich isotherm was introduced by Sips in 1948. When the adsorbate concentration is low, this isotherm reduces to Freundlich isotherm, and when the adsorbate concentration is high, this isotherm reduces to Langmuir isotherm ${ }^{25}$. This model is based on the following equation:

$q_{\theta}=\frac{q_{m}\left(K_{a} C_{e}\right)^{\alpha}}{1+\left(K_{a} C_{\varepsilon}\right)^{\alpha}}$

where $\mathrm{K}_{\mathrm{a}}$ is sips model constant $\left(\mathrm{L} \mathrm{mg}^{-1}\right)$ and $\alpha$ is Sips model exponent. The $R^{2}$ value for Sips isotherm is 0.99095 , which shows that the experimental data have a better agreement with this isotherm. The value of á is closer to 1, indicating that the adsorption of $\mathrm{Cr}(\mathrm{VI})$ onto $\mathrm{NiO}$ nanoparticles is approaching Langmuir form more than Freundlich form ${ }^{22}$.

\section{Toth isotherm}

This isotherm is associated with the potential theory ${ }^{8}$ and is based on the following equation:

$q_{e}=\frac{q_{m} K_{T H} C_{e}}{\left\lfloor 1+\left(K_{T H} C_{e}\right)\right]^{\frac{1}{\beta}}}$

where $\mathrm{K}_{\mathrm{Th}}$ is Toth model constant $\left(\mathrm{L} \mathrm{mg}^{-1}\right)$ and â is Toth model exponent. Toth isotherm can be 
reduced into the Henry law in low concentrations and to Langmuir model when â is equal to one.

The $\beta$ value is 0.94 , which indicates that the isotherm is approaching the Langmuir model.

\section{Adsorption kinetic studies}

The rate of reaction is one of the key factors in designing of the adsorption systems. In this study, pseudo-first-order and pseudo-second-order kinetic models were investigated to find the best- fitted model for the experimental data. The plot of nonlinear regression of these models to the experimental data is shown in scheme 12. Also, all the parameters of these models are listed in Table 3.

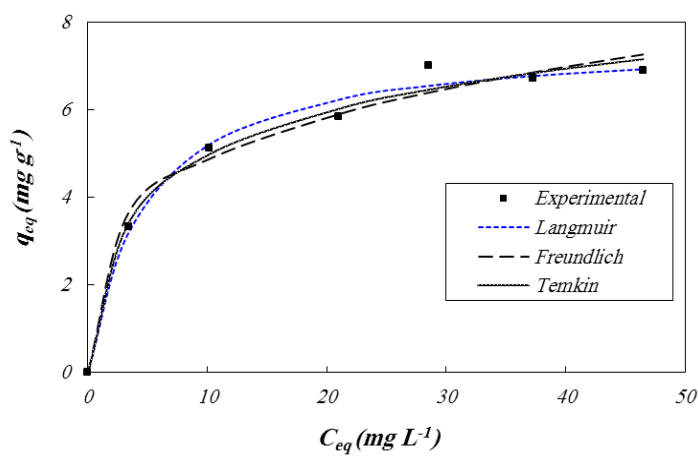

Scheme 10: Comparison of 2-parameter isotherm models for adsorption of $\mathrm{Cr}(\mathrm{VI})$ from aqueous solutions by $\mathrm{NiO}$ nanoparticles $\left(\mathrm{NiO}=0.2, \mathrm{pH}=4.7, \mathrm{~T}=20^{\circ} \mathrm{C}\right)$

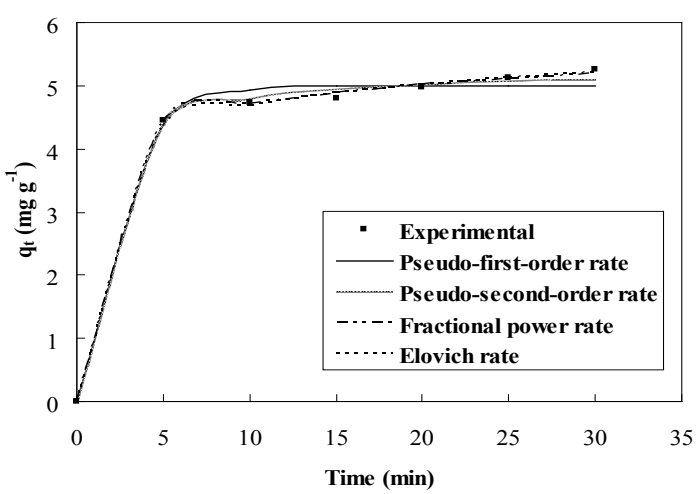

Scheme 12: Comparison of kinetic models for adsorption of $\mathrm{Cr}(\mathrm{VI})$ onto $\mathrm{NiO}$ nanoparticles

$$
\begin{gathered}
\left(\mathrm{NiO}=0.2 \mathrm{~g},[\mathrm{Cr}] 0=20 \mathrm{mg} \mathrm{L}^{-1},\right. \\
\left.\mathrm{pH}=4.7, \mathrm{~T}=20^{\circ} \mathrm{C}\right)
\end{gathered}
$$

\section{Pseudo-first order kinetic model}

This model is based on the following equation:

$q_{t}=q_{\theta}\left(1-e^{-k_{1} t}\right)$

where $q_{t}$ and $q_{e}$ are the amounts of $\mathrm{Cr}(\mathrm{VI})$ adsorbed at contact time of $t$ and at equilibrium $\left(\mathrm{mg} \mathrm{g}^{-1}\right)$, respectively. $\mathrm{k}_{1}$ is pseudo-first order kinetic model rate constant $\left(\mathrm{min}^{-1}\right)$. As shown in Table 3 , the $\mathrm{R}^{2}$ and $\mathrm{R}^{2}$ adj of this model are lower than Pseudosecond order kinetic model, and $\mathrm{R}_{\mathrm{msd}}$ is higher than it. This suggests that the kinetics of $\mathrm{Cr}(\mathrm{VI})$ adsorption on $\mathrm{NiO}$ nanoparticles did not follow the pseudo-firstorder kinetic model.

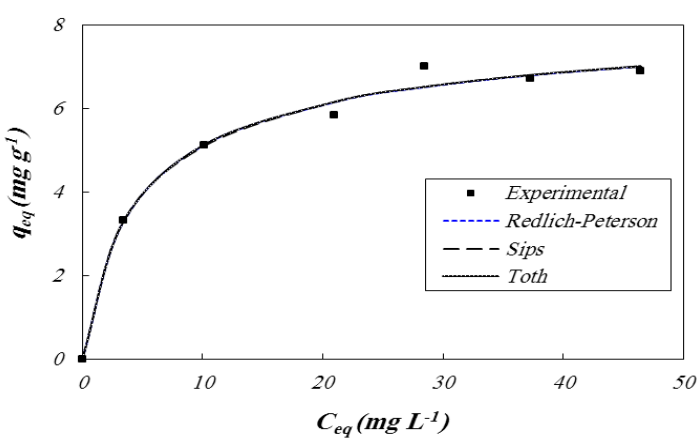

Scheme 11: Comparison of 3-parameter isotherm models for adsorption of $\mathrm{Cr}(\mathrm{VI})$ from aqueous solutions by $\mathrm{NiO}$ nanoparticles $\left(\mathrm{NiO}=0.2 \mathrm{~g}, \mathrm{pH}=4.7, \mathrm{~T}=20^{\circ} \mathrm{C}\right)$

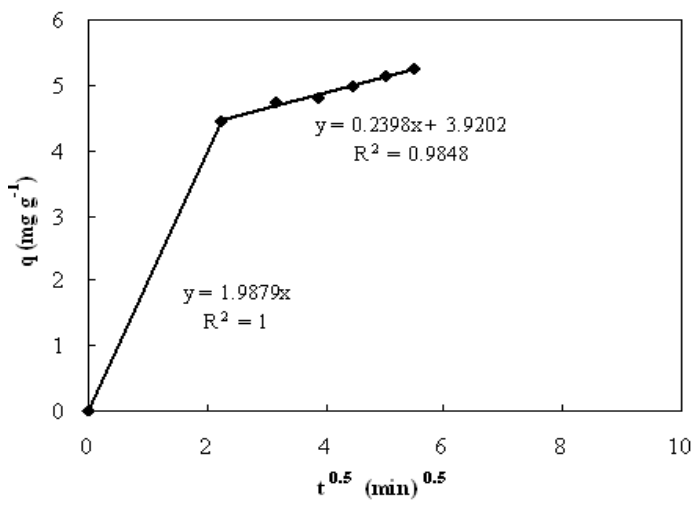

Scheme 13: The intra-particle diffusion plot for adsorption of $\mathrm{Cr}(\mathrm{VI})$ onto $\mathrm{NiO}$ nanoparticles

$\left(\mathrm{NiO}=0.2 \mathrm{~g},[\mathrm{Cr}] 0=20 \mathrm{mg} \mathrm{L}^{-1}\right.$, $\mathrm{pH}=4.7, \mathrm{~T}=20^{\circ} \mathrm{C}$ ) 
Pseudo-second order kinetic model

This model is based on the following equation:

$q_{t}=\frac{q_{2}^{\pi} k_{2} t}{1+k_{2} q_{e} t}$ where $\mathrm{k}_{2}$ is pseudo-second order kinetic model rate constant $\left(\mathrm{g} \mathrm{mg}^{-1} \mathrm{~min}^{-1}\right)$. According to the results shown in Table 2 and scheme 12, this model has satisfactorily fit to the experimental data, as indicated by $R^{2}, R_{\text {adj }}^{2}$ and $R_{m s d}$. This model demonstrates the occurrence of two reactions: the

Table 1: Isotherm model parameter values $( \pm 95 \%$ confidence level)

\begin{tabular}{lccccc}
\hline Model & R2 & R2adj & Rmsd & Parameters & Parameters values \\
\hline 2-p Langmuir & 0.99007 & 0.98808 & 0.08911 & $\mathrm{qmK}_{\mathrm{L}}$ & $7.63( \pm 0.67)$ \\
& & & & & $0.21( \pm 0.09)$ \\
2-p Freundlich & 0.98172 & 0.97806 & 0.12089 & $\mathrm{~K}_{\mathrm{F}}$ & $2.65( \pm 0.0018)$ \\
& & & & $\mathrm{n}$ & $3.81( \pm 0.003)$ \\
2-p Temkin & 0.98859 & 0.98631 & 0.09550 & $\Delta \mathrm{Q}\left(\mathrm{J} \mathrm{mol}^{-1}\right)$ & $1705.16( \pm 421.54)$ \\
& & & & $\mathrm{KT}$ & $3.24( \pm 3.34)$ \\
3-p Redlich- & 0.99074 & 0.98611 & 0.08604 & $\mathrm{~A}$ & $1.95( \pm 2.34)$ \\
Peterson & & & & $\mathrm{B}$ & $0.32( \pm 0.76)$ \\
& & & & $\mathrm{g}$ & $0.94( \pm 0.3)$ \\
3-p Sips & 0.99095 & 0.98643 & 0.08505 & $\mathrm{q}_{\mathrm{m}}$ & $8.25( \pm 0.14)$ \\
& & & & $\mathrm{K}_{\mathrm{a}}$ & $0.18( \pm 0.01)$ \\
& & & & $\alpha$ & $0.82( \pm 0.05)$ \\
3-p Toth & 0.99074 & 0.98611 & 0.08604 & $\mathrm{q}_{\mathrm{m}}$ & $6.90( \pm 4.39)$ \\
& & & & $\mathrm{K}_{\mathrm{Th}}$ & $0.3( \pm 0.64)$ \\
& & & & $\beta$ & $0.94( \pm 0.3)$
\end{tabular}

Table 2: Adsorption capacity of metal oxides for $\mathrm{Cr}(\mathrm{VI})$

\begin{tabular}{lccc}
\hline Adsorbent & Synthesis method & qm $(\mathbf{m g ~ g - 1 )}$ & Reference \\
\hline $\mathrm{NiO}$ & Precipitation & 4.73 & {$[11]$} \\
$\mathrm{SnO} 2$ & Precipitation & 3.09 & {$[9]$} \\
$\mathrm{ZnO}$ & Precipitation & 9.38 & {$[9]$} \\
$\mathrm{NiO}$ & Sol-gel & 7.63 & This work \\
\hline
\end{tabular}

Table 3: Adsorption kinetics parameter values $( \pm 95 \%$ confidence level)

\begin{tabular}{lccccl}
\hline Model & R2 & R2adj & Rmsd & Parameters & Parameters values \\
\hline $\begin{array}{l}\text { Pseudo-first } \\
\text { order kinetic }\end{array}$ & 0.99261 & 099114 & 0.05613 & $\mathrm{~K} 1$ & $0.42( \pm 0.16)$ \\
$\begin{array}{l}\text { model } \\
\begin{array}{l}\text { Pseudo- } \\
\text { second order }\end{array}\end{array}$ & 0.99745 & 0.99695 & 0.023295 & $\mathrm{q}_{\mathrm{e}}$ & $5( \pm 0.21)$ \\
kinetic model & & & & $\mathrm{q}_{\mathrm{e}}$ & $5.29( \pm 0.22)$ \\
\hline
\end{tabular}


first one is fast and reaches equilibrium quickly; the second is slow and can continue for a long time ${ }^{26}$.

\section{Intra-particle diffusion kinetic model}

The adsorption of $\mathrm{Cr}(\mathrm{VI})$ on $\mathrm{NiO}$ nanoparticles may be controlled via external film diffusion and later by the intra-particle diffusion. Intra-particle diffusion kinetic model can be expressed as follows:

$q=k_{i p} t^{0.5}+C$

where $k_{i p}$ is intra-particle diffusion kinetic model rate constant ( $\left.\mathrm{mg} \mathrm{g}^{-1} \mathrm{~min}^{-0.5}\right)$. Scheme 13 shows the intra-particle diffusion kinetic plot for the adsorption of $\mathrm{Cr}(\mathrm{VI})$ on $\mathrm{NiO}$ nanoparticles. According to this plot, there are two steps involved in the process. The first region corresponds to instantaneous adsorption on the external surface, and the second region is the gradual adsorption. In the other words, the second linear portion is due to intra-particle diffusion or pore diffusion. Therefore, the slope of the second linear portion of the plot has been considered the $\mathrm{k}_{\mathrm{ip}}{ }^{26,27}$.

\section{CONCLUSION}

Nanosized $\mathrm{NiO}$ material was prepared by sol-gel method. The $\mathrm{NiO}$ nanoparticles were characterized by XRD, TEM, SEM, EDX and BET-BJH surface area analysis. The average crystallite size of $\mathrm{NiO}$ nanoparticles was about 7 $\mathrm{nm}$. The TEM results showed that there was a good agreement between the TEM and XRD results for the particle size. The BET analysis showed that the specific surface area and total pore volume of $\mathrm{NiO}$ nanoparticles were $109.36 \mathrm{~m}^{2} \mathrm{~g}^{-1}$ and $0.1993 \mathrm{~cm}^{3}$ $\mathrm{g}^{-1}$, respectively. The SEM micrograph indicated that the $\mathrm{NiO}$ had uniform size distribution. The effect of $\mathrm{Cr}(\mathrm{VI})$ initial concentration revealed the decrease of adsorption percentage with the decrease of $\mathrm{Cr}(\mathrm{VI})$ concentration but the rise of the adsorption percentage with an increase in the dosage of the $\mathrm{NiO}$ nanoparticles. It was also found that the isotherm model and adsorption kinetics followed Sips isotherm and pseudo-second order kinetic model, respectively.

\section{ACKNOWLEDGEMENT}

The authors gratefully acknowledge Islamic Azad University, North Tehran Branch, for providing facilities.

\section{REFERENCES}

1. Sheela, T., Arthoba Nayaka, Y., Kinetics and thermodynamics of cadmium and lead ions adsorption on $\mathrm{NiO}$ nanoparticles, Chem. Eng.J. 2012, 91, 123-131.

2. Cheng, B., Le, Y., Cai, W., Yu, J., Synthesis of hierarchical $\mathrm{Ni}(\mathrm{OH})_{2}$ and $\mathrm{NiO}$ nanosheets and their adsorption kinetics and isotherms to Congo red in water, J. Hazard. Mater. (2011), 185, 889-897.

3. Mahmood, T., Saddique, M.T., Naeem, A., Mustafa, S., Zeb, N., Shah, K.H., Waseem, M., Kinetic and thermodynamic study of $\mathrm{Cd}(\mathrm{II}), \mathrm{Co}(\mathrm{II})$ and $\mathrm{Zn}(\mathrm{II})$ adsorption from aqueous solution by $\mathrm{NiO}$, Chem. Eng.J. (2011), 171, 935-940.

4. Mahmood, T., Din, S.U., Naeem, A., Mustafa, S., Waseem, M., Hamayun, M., Adsorption of arsenate from aqueous solution on binary mixed oxide of iron and silicon, Chem. Eng.J
(2012), 192, 90-98.

5. Hosny, N.M., Synthesis, characterization and optical band gap of $\mathrm{NiO}$ nanoparticles derived from anthranilic acid precursors via a thermal decomposition route, Polyhedron. (2011), 30, 470-476.

6. Wu, Y., He, Y., Wu, T., Weng, W., Wan, H., Effect of synthesis method on the physical and catalytic property of nanosized $\mathrm{NiO}$, Mater. Lett., (2007), 61, 2679-2682.

7. Lifang, Ch., Juncheng, H., Ryan, R., Nio nanosheets as efficient and recyclable adsorbents for dye pollutant removal from wastewater, Nanotech., (2009),20, 275707

8. Behnajady, M.A., Yavari, Sh. Modirshahla, N., Investigation on adsorption capacity of $\mathrm{TiO}_{2}-\mathrm{P} 25$ nanoparticles in the removal of a manono-azo dye from aqueous solution: $A$ comprehrnsive isotherm analysis, Chem. Ind. 
Chem. Eng. Q. (2014), 20, (1) 97-107.

9. Kumar, K. Y., Muralidhara, H.B., Arthoba Nayaka, Y., Balasubramanyam, J., Hanumanthappa , H., Low-cost synthesis of metal oxide nanoparticles and their application in adsorption of commercial dye and heavy metal ion in aqueous solution, Powder. Tech. (2013), 246,125-136.

10. Mohapatra, P., Samantaray, S.K., Parida, K., Photocatalytic reduction of hexavalent chromium in aqueous solution over sulphate modified titania, J. Photochem. Photobiol., A, (2005), 170, 189-194.

11. Behnajady, M. A., Bimeghdar, S., Synthesis of mesoporous $\mathrm{NiO}$ nanoparticles and their application in the adsorption of $\mathrm{Cr}(\mathrm{VI})$, Chem. Eng. J. (2014), 239,105-113.

12. Chowdhury, S., Mishra, R., Saha, P., Kushwaha, P., Adsorption thermodynamics, kinetics and isosteric heat of adsorption of Malachite Green onto chemically modified rice husk, Desalination . (2011), 265, 159168

13. Mahmood, T., Saddique, M.T., Naeem, A., Mustafa, S., J. Hussain, B. Dilara, Cation exchange removal of $\mathrm{Zn}$ from aqueous solution by $\mathrm{NiO}$, J. Non-Crystalline Solids. (2011), 357, 1016-1020.

14. Dashti Khavidaki, H., Aghaie, H., Shishehbore, M. R. , Adsorption of thallium (III) ion from aqueous solution using modified $\mathrm{ZnO}$ nanopowder, J. Phys. Theor. Chem. IAU Iran. (2011), 8, (3) 233-244.

15. Gonen, F., Serin, S., Adsorption study on orange peel: Removal of $\mathrm{Ni}(\mathrm{II})$ ions from aqueous solution, Afr. J. Biotechnol. (2012) ,11, 1250-1258.

16. Ozacar, M., Sengil, I.A., Adsorption of metal complex dyes from aqueous solutions by pine sawdust, Bioresour. Technol. (2005), 96 , 791-795.

17. Ranran, W., Qiurong, L., Danyang, X., Haiyan, X., Hongxiao, L., Synthesis of NiO using pine as template and adsorption performance for $\mathrm{Pb}$ (II) from aqueous solution, Appl. Surface. Sci. (2013), 279,129-136
18. Naeem, A., Saddique, M.T., Mustafa, S., Tasleem, S., Shah, K.H. , Waseem, M., Removal of $\mathrm{Co}^{+2}$ ions from aqueous solution by cation exchange sorption onto $\mathrm{NiO}, \mathrm{J}$. Hazard. Mater. (2009), 172, 124-128.

19. Modirshahla, N., Behnajady, M. A., Shamel, A., Eskandari, H., Sorption study of C.I. Acid Red 88 from aqueous solutions onto sawdust, J. Phys. Theor. Chem. IAU Iran. (2010), 7, (2) 77-81.

20. Nandi, B.K., Goswami, A., Purkai, M.K. , Adsorption characteristics of brilliant green dye on kaolin, J. Hazard, Mater, (2009), 161, 387-395.

21. El-khaiary, M.I., Malash, G.F., Ho, Y.S., On the use of linearized pseudo-secondorder kinetic equation for modeling adsorption systems, Desalination. (2010), 257, 93-101.

22. Ho, Y.S., Prter, J.F., Mckay, G., Equilibrium isotherm studies for the sorption of divalent metal ions onto peat: copper, nickel and lead single component systems, Water Air Soil Pollut., (2001), 141, 1-33.

23. Nuengmatcha, P., Mahachal, R., Chanthal, S., Thermodynamic and kinetic study of the intrinsic adsorption capacity of graphene oxide for malachite green removal from aqueous solution, Oriental journal of chemistry. (2014), 30, 1463-1474.

24. Hameed, B.H., Tan, I.A.W., Ahmad, A.L., Adsorption isotherm, kinetic modeling and mechanism of 2,4,6-trichlorophenol on coconut husk-based activated carbon, Chem. Eng. J. (2008), 144, 235-244.

25. Subramanyam, B., Das, A., Study of the adsorption of phenol by two soils based on kinetic and isotherm modeling analyses, Desalination. (2009), 249, 914-921.

26. Alzaydien, A.S., Adsorption behavior of methyl orange onto wheat bran: Role of surface and $\mathrm{pH}$, Oriental journal of chemistry. (2015), 31,643-651.

27. Dogan, M., Abak, H., Alkan, M., Adsorption of methylene blue onto hazelnut shell: Kinetics, mechanism and activation parameters, $J$. Hazard. Mater., (2009), 164, 172-181. 